\title{
Memahami Lebih Dalam Mengenai Pentingnya Pencegahan Penularan Covid-19 Sejak Usia Dini di TPQ Al-Mubarok
}

\author{
Fajar Rohman Hariri \\ Jurusan Teknik Informatika, UIN Maulana Malik Ibrahim Malang \\ fajar@ti.uin-malang.ac.id
}

\section{Info Artikel}

Riwayat Artikel:

Diterima: Januari 2021

Direvisi: Februari 2021

Diterbitkan: Maret 2021

\section{Keywords:}

Prevention

Covid-19

Children

\begin{abstract}
It takes an intensive understanding of the corona virus and how to deal with it so that the spread rate does not increase. Especially early childhood, including those who are vulnerable to the Covid-19 virus because they do not understand how fast this virus spreads and still have an immune system that is vulnerable to the virus. With the Covid19 virus, it has resulted in children being unable to study at school, so learning activities must also be supported by parents at home and teachers are also responsible for monitoring children's learning activities. This Covid-19 virus also brings fear and worry to children, this is because children do not understand how they understand the virus and how to prevent it. Therefore, it is very important to carry out socialization or education about the prevention of Covid-19 for children -child. Covid-19 prevention education contains the introduction of the Covid-19 virus, how to deal with worry, and how to prevent the Covid-19 virus through short animated videos that are interesting and easy for children to understand, so that children's worries can be reduced and parents will also understand how to teach children to prevent the virus.
\end{abstract}

Copyright (C) 2021 JRCE. All rights reserved.

\section{Korespondensi: \\ Fajar Rohman Hariri, UIN Maulana Malik Ibrahim Malang, \\ Jl. Gajayana No. 50 Malang, Jawa Timur, Indonesia 65144 \\ fajar@ti.uin-malang.ac.id}

\section{PENDAHULUAN}

Hal terpenting dalam kehidupan manusia adalah kesehatan. Namun yang terjadi di Indonesia saat ini adalah maraknya penyakit Covid-19 yang disebabkan oleh virus corona yang dapat menyebabkan kematian. Virus ini terdeteksi muncul pertama kali di Wuhan, China pada bulan Desember 2019. Virus corona merupakan virus yang menyerang saluran pernafasan dan menyebabkan demam tinggi, batuk, flu, sesak nafas serta nyeri tenggorokan.

Akibat dari maraknya virus corona ini mengakibatkan berbagai hal dikerjakan dari rumah, baik sekolah, kuliah, bekerja ataupun aktivitas lainnya. Bahkan tempat beribadah pun sebagian telah ditutup demi mengurangi penyebaran virus corona ini. Berbagai cara telah dilakukan oleh pemerintah, seperti social distancing, lockdown, bahkan di beberapa daerah pun telah diberlakukan PSBB (pembatasan sosial berskala besar). Namun masih banyak masyarakat yang tidak mematuhi peraturan tersebut hingga akhirnya penyebaran virus ini berjalan begitu cepat.

Dengan demikian, dibutuhkan pemahaman yang intensif mengenai virus corona serta cara menanggulanginya agar angka penyebaran tidak semakin meningkat. Khususnya anak usia dini, termasuk 
golongan yang rentan terkena virus Covid-19 dikarenakan belum memahami bagaimana cepatnya penyebaran virus ini dan masih memiliki sistem imun yang rentan dengan virus. Dengan adanya virus Covid-19, mengakibatkan anak-anak tidak dapat belajar di sekolah, sehingga aktivitas belajar juga harus didukung oleh orang tua di rumah dan guru juga tetap bertanggung jawab memantau aktivitas belajar anak-anak. Virus Covid19 ini juga membawa rasa takut dan khawatir dalam diri anak, hal ini disebabkan karena anak belum memahami dengan cara mereka mengenai virus tersebut dan cara pencegahannya.

Oleh karena itu, penting sekali untuk melaksanakan sosialisasi atau edukasi tentang pencegahan Covid-19 bagi anak-anak. Edukasi pencegahan Covid-19 berisi tentang pengenalan virus Covid-19, cara mengatasi rasa khawatir, serta cara pencegahan virus Covid-19 melalui video animasi pendek yang menarik dan mudah dipahami oleh anak, sehingga rasa khawatir anak akan dapat berkurang dan orang tua juga akan paham bagaimana mengajarkan anak untuk mencegah virus tersebut.

\section{METODE PENELITIAN}

Pelaksanaan kegiatan sosialisasi dan edukasi pencegahan Covid-19 bertempat di TPQ Al-Mubarok Desa Ngenep Karangploso Malang ini dihadiri oleh para siswa/i beserta orang tua yang mendampingi mereka. Pelaksanaan program kegiatan penyuluhan pencegahan penularan Covid-19 dilaksanakan secara bersamaan dengan edukasi mengenai pentingnya sikap moderasi dalam beragama. Program kegiatan ini dilakukan selama 1 hari yakni pada hari Selasa, 5 Januari 2021. Sasaran kegiatan kami ini adalah para siswa/i TPQ Al-Mubarok.

\section{HASIL DAN PEMBAHASAN}

Respon dari anak-anak dan orang tua mereka terkait program kegiatan ini sangatlah positif dan mendukung dengan baik, hal ini terbukti dari mereka yang aktif dalam mengikuti dan merespon proses kegiatan. Selain itu, para siswa/i TPQ Al-Mubarok sangat senang dan menunjukkan ekspresi keceriaan serta sangat antusias dalam proses kegiatan pengabdian masyarakat ini. Selama proses program kegiatan ini, kemampuan pemahaman anak tentang Covid-19 sudah mulai nampak, terlihat ketika proses kegiatan berlangsung para siswa/i sudah mampu memahami bahwa Covid-19 dengan cara mereka dimana virus ini yaitu virus yang dapat menyebabkan sakit jika kita tidak menjaga kesehatan, anak-anak juga paham bagaimana cara menjaga kesehatan agar terhindar dari virus tersebut, yaitu dengan cara rajin mencuci tangan, selalu menggunakan masker jika akan keluar rumah, makan makanan bergizi dan selalu menerapkan pola hidup sehat. Para orang tua siswa juga merasa antusias dalam menemani anak-anak ketika tim pengabdian memberikan materi mengenai Covid-19 melalui tayangan video animasi youtube.

Selain menampilkan video animasi youtube, juga memberikan edukasi tentang virus corona yang disampaikan oleh Mahasiswa KKM-DR. Materi edukasi ini merupakan materi yang telah disusun untuk memudahkan para siswa/i TPQ dalam memahami virus Covid-19 dan disajikan dengan cara menyenangkan sehingga mudah diterima oleh anak-anak. Karena anak-anak senang dengan kegiatan bercerita atau mendongeng, maka salah satu metode yang digunakan oleh Mahasiswa KKM adalah dengan bercerita menarik tentang virus corona juga mengajari tentang tata cara pemakaian masker, mencuci tangan dengan benar dan selalu mentaati protokol kesehatan yang telah disampaikan. Setelah penjelasan edukasi dari kami, tak lupa pula anak-anak ikut mempraktekkan langsung di depan, dengan demikian anak-anak mudah memahami, tidak takut atau khawatir, dan dapat mempraktekkan pencegahan penularan virus ini dalam kehidupan sehari-hari.
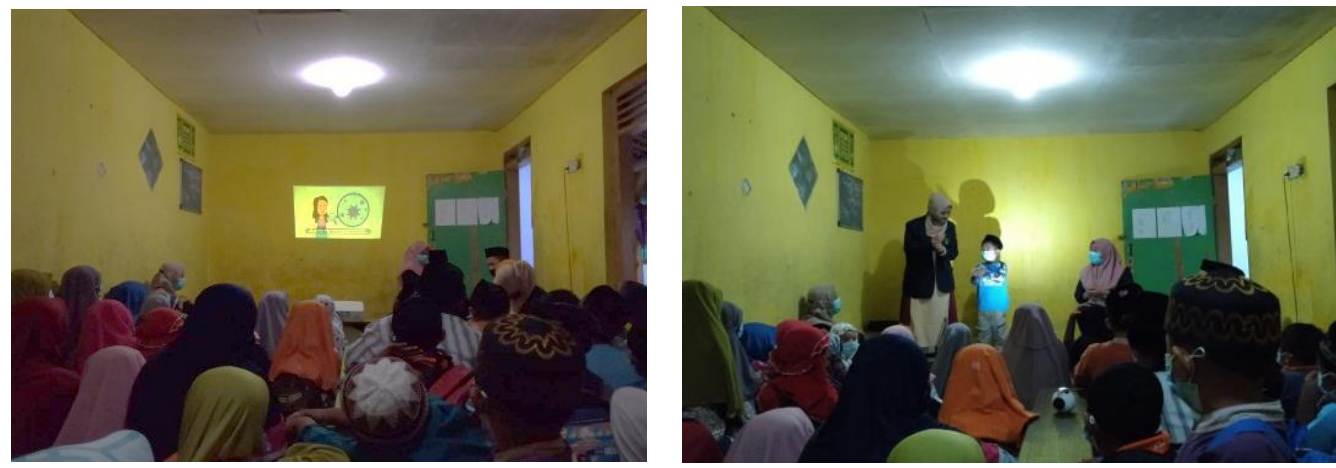

Gambar 1. Penyuluhan Covid-19 melalui tayangan video animasi 
Setelah memberikan pemahaman secara umum tentang virus corona dengan cara yang menarik atau cara yang mudah dipahami anak-anak, maka berikut langkah-langkah pencegahan yang bisa mereka lakukan agar terhindar dari virus corona, seperti :

1.Rutin mencuci tangan dengan sabun di bawah air mengalir hingga bersih sesuai imbauan.

2.Menggunakan masker saat keluar rumah.

3.Mengurangi kegiatan di luar rumah

4.Selalu menjaga jarak dengan orang lain (Social distancing)

5.Sebaiknya tidak memegang wajah, telinga, mulut, hidung, jika belum mencuci tangan hingga bersih.

6.Memakan makanan yang sehat dan bergizi agar daya imun semakin kuat.

Sebelum program kegiatan ini selesai, Mahasiswa KKM-DR membagikan masker dan hand-sanitizer kepada para siswa/i TPQ Al-Mubarok beserta orang tua mereka guna melatih untuk selalu mematuhi protokol kesehatan.
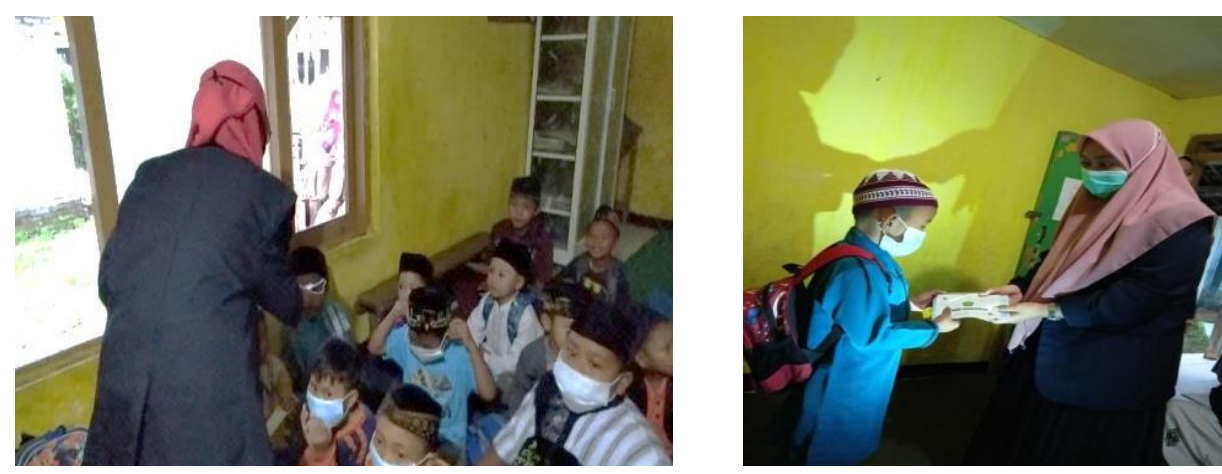

Gambar 2. Pembagian masker kepada para siswa/i TPQ

Selain itu, Mahasiswa KKM-DR juga melakukan penyuluhan Covid-19 kepada masyarakat Desa Ngenep dengan memasang banner tentang penyuluhan Covid-19. Sistem ini sangat berguna untuk upaya pencegahan virus Covid-19. Kami memasang banner di depan balai desa tepi jalan raya, karena tempat ini sangat strategis sering dijumpai oleh banyak orang, sehingga masyarakat selalu memperhatikan akan pentingnya mematuhi protokol kesehatan.
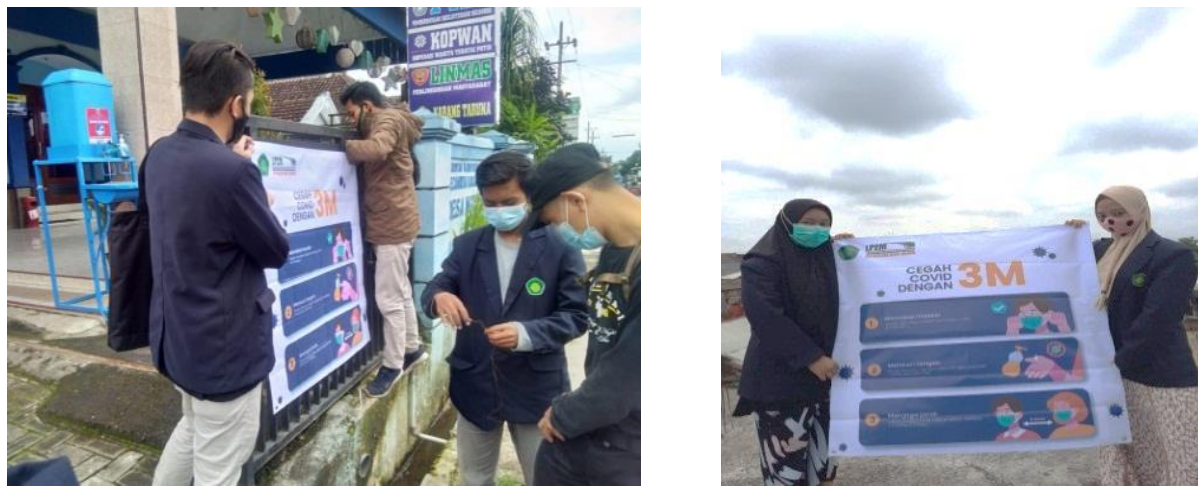

Gambar 3. Pemasangan banner Covid19 


\section{KESIMPULAN}

Berdasarkan uraian di atas maka dapat disimpulkan bahwa pelaksanaan program kegiatan tentang sosialisasi dan edukasi pencegahan penularan Covid-19 bagi anak-anak terlaksana dengan baik, dan memberikan dampak yang positif bagi anak, bagi lembaga TPQ Al-Mubarok, bagi orang tua, dan masyarakat. Sehingga kedepannya perlu adanya program kegiatan serupa, yang dapat mendukung kegiatan belajaranakanak dari rumah dengan menyediakan kegiatan yang bermanfaat serta membantu pertumbuhan dan perkembangan anak agar berkembang dengan baik.

\section{DAFTAR PUSTAKA}

[1] H. H. Batubara and D. N. Ariani, "Pemanfaatan Video sebagai Media Pembelajaran Matematika SD/MI," Muallimuna J. Madrasah Ibtidaiyah, vol. 2, no. 1, p. 47, Oct. 2016, doi: 10.31602/muallimuna.v2i1.741.

[2] D. R. Buana, “Analisis Perilaku Masyarakat Indonesia dalam Menghadapi Pandemi Virus Corona (Covid-19) dan Kiat Menjaga Kesejahteraan Jiwa," SALAM J. Sos. dan Budaya Syar-i, vol. 7, no. 3, pp. 217-226, Mar. 2020, doi: 10.15408/sjsbs.v7i3.15082.

[3] L. Hewi and L. Asnawati, "Strategi Pendidik Anak Usia Dini Era Covid-19 dalam Menumbuhkan Kemampuan Berfikir Logis,” J. Obs. J. Pendidik. Anak Usia Dini, vol. 5, no. 1, p. 158, May 2020, doi: 10.31004/obsesi.v5i1.530.

[4] N. R. Yunus and A. Rezki, "Kebijakan Pemberlakuan Lock Down Sebagai Antisipasi Penyebaran Corona Virus Covid-19," SALAM J. Sos. dan Budaya Syar-i, vol. 7, no. 3, pp. 227-238, Mar. 2020, doi: $10.15408 /$ sjsbs.v7i3.15083. 